\title{
10. To protect the Amazon, defend the people of the forest
}

\author{
Maria do Socorro Costa Silva
}

I am a defender of the rivers and forest of the Amazon, representing about 20000 people in my organization, Cainquiama. They chose me as president because I am one of them, because the struggle is in my blood.

I am a quilombola - a descendant of African slaves who escaped captivity and made a home deep in the Amazon rainforest in the late nineteenth century. I am also partly indigenous. One of my grandfathers was from a tribe here in the northern state of Pará. For many years, my community was hidden. The first record of my people was recorded by a group of Jesuit missionaries who came to Murucupi, the headwater of the Pará River, more than 100 years ago. They counted 157 residents in our settlement in what is now Barcarena. Among them was my great-grandmother, Januária. At that time, this was a land of great abundance. Ample fresh water, good land and lots of fish. That has changed in my lifetime.

I was born in 1965. Around the age of five, I started to notice how "progress" was encroaching on our village. First came a ferry service that connected our island to other towns. My parents were happy about that. I was not too pleased. The port took the land where we used to bathe. And the ferry brought handsome men in beautiful clothes who studied our land and left with notes and surveys. Back then, the military dictatorship that ruled Brazil described the Amazon as a "land without men for men without land". Human beings like us did not exist for the white elites, except to be ravaged like the forest. My parents were uneasy, but they didn't know what to say. Then came the road, ripping through the forest and covering over the streams. In 1973, an accommodation block was built on top of the ancient woods where I used to collect Brazil nuts, which staved off hunger. More and more construction work opened up the region.

My uncle and aunt were hired to help with the projects. Their bosses took a shine to me. I was only 14, but very pretty. My uncle and aunt encouraged me to start consorting with a director of the company. It was the same for many of the girls in my community. Many of us were raped. Many of us were forced to have abortions. I do not cry about this because I am tough. I am an activist. 
But I have to mention these crimes so they don't happen again. They are crimes against women and children and they are crimes against the forest and the river. As I was being sexually abused, more outsiders moved in and forced out existing families. They expropriated land and opened up a wide area for an orange grove. It was so small-minded and destructive. They had no care for the giant Brazil nut tree that had been growing for more than generations. That was the real wealth of our people. It was part of our identity. My grandparents felt helpless, but I knew something was wrong.

In 1984, our community took another step towards "progress". Barcarena became a municipality and we got our first mayor, council and notary office. This did not mean more rights; it meant more laws and rules were imposed on us. It provided legal justification for the expulsion of forest dwellers. This was around the time I decided I had to fight back.

Our houses were made of clay, straw and sticks. For me, this was home. I wanted to remain where I had grown up. I wanted to stay until my dying day. But the regulations demanded we leave. The regulations demanded the community school be demolished. I was pressured to have sex with a foreign man. There was no wedding. I conceived and miscarried. My parents and grandparents were ordered to find new homes. They gave in. Our old homes were destroyed. No one gave us a choice. The government's priority was to ensure huge new mines could be opened up in our area. It was perfect for mineral companies because they need water and we had lots of that.

Now, nobody lives where we once had our homes. Instead, we have one of the world's biggest bauxite pits and aluminium factories. The Norwegian firm Hydro Alunorte (Norsk Hydro in its own country) buys ore from the mining firm Paragominas and then processes it here in Barcarena using water from the river. The effluent goes back into the river - millions and millions of litres of caustic soda, uranium, alumina, lead and nickel. They say it is treated, but these metals corrode. Our rivers and our forest have been poisoned. Every day we drink this water and die a little. I believe I am living proof of that. I have cancer. For me, there is no doubt that this came from heavy metals. I drank from the contaminated river, I bathed in it, I cooked my food with water I took from it. It is not just me. Eight members of my family have cancer, including my grandson. The future generation is born and dies. The company denies irregularities, but this is not just my imagination. In March 2018, the Evandro Chagas Institute, part of the Brazilian Health Ministry, detected high levels of aluminium, iron, copper, arsenic, mercury, and lead in the Murucupi River. Brazilian courts temporarily halted part of production at Alunorte, but it is back up and running. Once again, we are suffering for the world's non-stick pots and pans, beer barrels, and plane parts.

"So what?" you might ask. Why shouldn't industry and progress come before the health of forest dwellers like me? Well, you need to think about 
what you want. If you want to stabilize the climate, or protect wildlife, then we are important. If you want to care for the forest, you need to take care of us because nobody looks after the forest better than those who have lived in it for generations. We don't have huge destructive mines or plantations. Whatever we plant, we harvest 70 per cent and leave 30 per cent to feed animals.

What is this progress we are promised? The words are always very beautiful - fine houses, more gold, welfare, environmental protection. It is all a lie. They have destroyed our land and water, and with it they have taken my past and my present. We cannot eat aluminium. All the benefits go overseas to the shareholders in different countries, to people who buy things we cannot afford.

That is my message, but a message is not enough. We need to be brave. We need to fight. I live in the most murderous state in the most murderous country in the world for environmental defenders. My home is just 700 metres from the factory. My colleagues have been murdered for this fight. I have had a pistol pressed against my face. Yet I have filed more than 40 lawsuits against the world's biggest aluminium company. And I will file more if necessary. And I will resist the local government and the courts, who are in the pocket of big business. And I will oppose the president of Brazil, who attacks quilombolas and indigenous people. I am not afraid. Until I am killed, I will speak out. This forest sustains the world. The people who live here sustain the forest. Without us, Brazil will suffer irreparable loss. Without us, there is no river, there are no animals, there is nothing. If you want to normalize the planet's temperature, you have to take care of us. Because without us there is no future generation.

Forest people need to unite. We need to be more political. I am not naive or backward or perfect. I want gold, I want a plasma TV, I want Nike brand products, I want good things. But I want health and a home most of all. I don't know if future generations will continue our fight. But we need to clean up the rivers. We want to take back control. What we really need is a forest people's republic and a forest people's president. Let us start in each city and spread this movement across the world. If you want to protect the Amazon, defend the people who traditionally live here. 